\title{
Malgorzata Domiter
}

Wrocław University of Economics

e-mail: malgorzata.domiter@ue.wroc.pl

\section{THE MEANING OF GLOBAL RULES OF LEADING TRADE WITH PARTICULAR FOCUS ON MFN FOR DEVELOPING COUNTRIES}

\begin{abstract}
Summary: This article is an attempt to indicate the role of trade politics in enabling particular countries to raise to the sphere of higher value added within the world trade. East Asia has succeeded using this type of politics, whereas Latin America has not. In each developing country, some advantages coming from the liberalization of import, which has been a part of strategy focused on confining poverty and accelerating the accrual, can be noticed. However, the construction of reforms, their sequence and the pace of implementing have decided about the effectiveness of the liberalization strategy. Notwithstanding this, the true economic success has been achieved only by developing countries which use the export growth politics. In the article, three theses are described: 1) foreign trade is a more powerful factor that furthers the development of the poorest countries than foreign aid and the role of the foreign trade increases with the general development of a country ${ }^{1}, 2$ ) foreign trade is determined by global rules of its operating, therefore, developing countries have to join in the system of international coordination of trade politics, 3) although MFN is used in a commercial treaty aspiring to regulate even worldwide business relations, the liberalization of the world trade, based on MFN, affects developing countries in a negative way, because with a downturn of general level of imposition, both the distinction and benefit from GSP system for the countries are decreasing.
\end{abstract}

Keywords: trade politics, rules of trade politics, developing countries, MFN.

DOI: $10.15611 / \mathrm{e} 21.2014 .4 .01$

\section{Introduction. Typology and definitions of developing countries}

A developing country is a country with relatively low real income accruing on a citizen in comparison with a more developed country [Samuelson, Nordhaus 2004, pp. 256-278]. Developing countries are also those countries in which salutariness and education, even on the basic level, are very low [Ekonomia rozwoju 2007]. The

\footnotetext{
${ }^{1}$ Developmental help is effective only in these countries which have good macroeconomics, dispose effective administration and public sector and lead open trade politics.
} 
ranking of countries in the group depends on a ranking institution ${ }^{2}$. In this group of countries, GDP per capita totals between 3 and 10,000 USD. Therefore, disparities between more developed countries and developing countries are wide. During comparisons made in the $1980 \mathrm{~s}$, it was verified that the income of developing countries was even 1/40 lower than in the USA. Since that time, an impressive economic increase in East Asia has been noticed. Countries from that region are still considered as developing countries, however, they are labeled as Asian economic tigers as well [Epping 2002, pp. 143-145]. The economies of South Korea, Singapore, Taiwan, Hong-Kong as well as Indonesia, Malaysia and Thailand belong to the group. Those countries, similarly to Japan, have based their economic development on export. Thanks to this development conception, they have reached economic growth so quickly that they have been ranked as advanced developing economics. In other words, they are known as New Industrialized Countries (NIC).

To sum up, following the subsystems of world economy may be distinguished:

1. More developed countries (triad of the USA, Japan and the EU).

2. Developing countries:

- newly industrialized countries (China, the Asian tigers),

- weakly industrialized countries (about 140 African, Latin American, Asian and Oceanian countries),

- countries of the East.

In this context, this article attempts to indicate the role of trade politics for developing countries in enabling them to raise to the sphere of higher value added within the world trade with particular focus on the Most Favored Nation (MFN).

\section{Institutionalization of international exchange and its influence on developing economies}

The disintegration of the colonial system released countries from economic dependence discovering equally a problem of disproportion between dominating and subjecting countries. Soon after gaining independence, countries of the Third World immediately took action to accelerate the economic development, mainly by building own economy and finding place on the international scene. It was possible by joining international organizations, furthering their development, and taking part in international trade in as much as possible. An important step towards the aim was convoking a special conference in Geneva in 1964, which triggered the development of international trade in economies of developing countries-UNCTAD - United Nations Conference on Trade and Development [Szpak 2003,

${ }^{2}$ OECD: countries with low income per citizen, new industrialized countries, countries with middle income per citizen, countries belonging to OPEC. World Bank: countries with low income, countries with middle low income, countries with middle income, countries with high income. United Nations: the weakest developed countries, oil developing countries, countries belonging to OPEC. 
p. 365].This institution coordinates international business in the area of economic cooperation and development policy. The institution works for changing law which regulates international trade in order to guarantee economic expansion and promotes international trade and growth of developing countries and cooperation among them.

Hitherto, 12 plenary sessions have taken place [Procesy integracyjne... 2007, pp. 50-150]. Respectively, they pertained to: approving privileged treatment of developing countries and attributing international trade a significant role in the economic growth of developing countries (Geneva 1964), the conclusion of an international accord into raw materials which have strategic significance for export of under-developed countries (New Delhi 1968), compiling the Charter of Economic Rights and Responsibilities of Countries (Santiago 1972), the coverage of consequences of debt crisis (Belgrade 1983), the indication of reasons and effects of restraining development and increasing protectionism (Geneva 1987), signing a declaration of cooperation between rich and poor countries (Mitrand 1996), equal participation of developing countries in the world economy and leading equitable trade negotiations (Sao Paulo 2004).

An initiative to create a universal international trade organization was established in the Interwar Period.

The General Agreement of Tariff and Trade (GATT) was emerged from negotiations which aimed to establish The International Trade Organization (ITO). Despite positive completion of the negotiations (Havana 1948), ITO was not founded because of the concern of denying a ratification for the treaty by the Congress of the USA. The GATT Treaty was negotiated on 30 October 1947 among 23 countries (12 developed countries and 11 developing countries), that is to say before completing the negotiations concerning ITO. GATT entered into force on 1 January 1948 after having signed and ratified the treaty from October 1947 by 8 countries from 23 signatories. The countries, which in 1947 committed themselves on mutual lowering of tariffs, afraid whether the implementation of liberalization was not dependent on the complementation of talks concerning ITO, brought to create GATT as a provisional treaty. For ITO did not come into existence, GATT appeared to be the only result of multilateral trade negotiations after the World War II. GATT fulfilled not only a function of multilateral treaty, which imposed delineated duties on signatories and guaranteed some rights, but also functioned as an international institution under whose auspices the initiatives and actions of the trade economy were taken. It was the main forum of the international trade liberalization in the post-war period.

The situation of GATT complicated in the middle of the 1950s due to the revalorization of its ideologies because of appearing of integration tendencies and increasing the importance of developing countries. Establishing of Euroasian Economic Community introduced elements of discrimination to trade contacts with the third countries. In 1955, Article XVIII of General Agreement was changed by 
contracting parties. The new text of the article indicates that developing countries should benefit from additional simplifications not budgeted for developed countries.

WTO was established on 1 January 1995 for the administration of trade agreement concluded by its members. Its establishment was justified by the need of creating flat institutional frames for the world trade. According to original aim, it was supposed to include modified GATT, twin service organs (GATS), intellectual property rights' organs (TRIPs) and treaties and accords signed under the auspices of Uruguay Round. However, this proposition was not accepted by the USA, which agreed on current view of the organization after negotiations. As the consequence, WTO is based on organizational structure developed under the auspices of GATT and its secretary from the beginning of the 1990s.

In accordance with the doctrinal basis, opening up of markets, lack of discrimination and global rivalry promote prosperity of each country. WTO, according to its assumptions, may fulfill the aims through inducting countries to conclude mutual commitment leading to liberalization [Latoszek, Proczek 2001, pp. 50-62].

\section{The role of the Most Favored Nation in the GATT/WTO system with particular insight of its significance for under-developed countries}

\subsection{The history of the Most Favored Nation and its codification in the international law}

The Most Favored Nation (MFN) has been present in international relations for ages. It has been known since the late Middle Ages in relations among European countries. Since that time, it has been ubiquitous in bilateral talks concerning non-preferential trade. It is also used in a commercial treaty aspiring to regulate world-wide trade relations.

\section{Definition and classifications of MFN}

Two mainstreams of defining the clause, such as a mainstream of international law and a mainstream connected with either international economy or international economic relations, can be distinguished. The definitions formed by experts of the international law are broad so that economic consequences of the clause may be deduced. Article I of GATT (The General Agreement on Tariffs and Trade) should be rated as the basis of all these definitions. In accordance with this article, each trade privilege given to one country by a member of the MFN, has to be immediately given to its other signatories. It underlines unconditionality of receiving such privileges and a rule that privileges should pertain to all similar/approximate products to the privileged ones. In some cases, a necessity to expand the clause understood as "provision of the treaty, which includes an obligation to grant facilitating 
simplifications, which are used or will be used by countries, goods and the most privileged citizens, available for citizens, legal persons possessing nationality quarter, goods and each other" [Kałduński 2006, pp. 114-117; http://www.wto.org; Hoekeman, Kostecki 2011, p. 211; Domiter 2008, p. 121; Michałek 2002, p. 119; Gilas 1976, p. 122] may be needed.

The classifications of MFN were established on the strength of three criteria:

1. In view of basis of the biggest privilege: international treaties, exchange of diplomatic notes and unilateral act of a country.

2. A unilateral clause, a bilateral clause and a multilateral clause: as far as the first one may be acknowledged as a relic of the past and an indication of non-equality of countries in international relations, inasmuch next two enacted and still enact an important role. Bilateral clauses were dominating for long time, till after the WW2 when multilateral clauses started to be used.

3. A negative clause, a positive clause and a double clause: a negative clause a country pledges not to make use of additional impediments and restrictions in relations with a partner embraced with a clause; a positive clause - each privilege given to the third country should be extended on partners with whom MFN is used; a double clause - combines both concepts.

As mentioned earlier, Art. I of GATT should be recognized as the main source of applying MFN in modern economic relations. That is why the MFN is multilateral, positive and has its source in an international treaty. It is connected with a fact that currently, 153 countries [http://www.wto.org/...] are the members of the World Trade Organization (in which GATT was re-named on 1 January 1995 [http://www. wto.org/... dated 02.05.2011]), so the range of its rules is global.

There is one more criterion of division of MFN, which has not been mentioned before. It is the division on an absolutely obligatory clause and a relative clause (dependent on conferring analogous powers by another country). This typology wears thin during analyzing the usage of the clause in economic relations because for members of the WTO, the clause is, ipso iure, absolutely obligatory.

Notwithstanding, in the system of GATT/WTO, there are some overall and individual exceptions to MFN.

For the individual exceptions, waivers, which are exemption of a quarter from duties consequent from the charter resolutions of the WTO, should be ranked. The waivers are temporary and have to be justified by special circumstances. A waiver, who allowed to use The Generalized System of Preferences (GSP) in trade relations of more developed countries with developing countries, belongs to the group of the most important waivers. Despite being originally anticipated for 10 years (from 1971 to 1981), GSP was included to the system by the simplification clause and still legitimizes trade among high- and under-developed economies. It is rated that only about $20 \%$ of allowed waivers have headed for larger, than anticipated in the frames of MFN, liberalization of trading so far. For instance, it concerns one-side preferences, which were granted for West Balkan countries by both the European 
Union and the European Free Trade Association (EFTA) [Domiter 2008, pp. 122-123; http://www.wto.org/..., dated 02.05.2011].

General departures from the Most Favored Nation clause are allowed by Article XXIV of GATT/WTO - general departure. The article sanctions both tightening of cooperation of countries in frames of free trade zones and customs unions or according to border privileges for neighboring countries in order to facilitate border traffic. Such privileges do not need to be accorded for other countries. Notwithstanding, creating privileges for other countries not according to specific customs is permissible. It is admissible if customs and other trade restrictions are not higher than those applied by member countries before establishing a customs union. It is described in point $5 \mathrm{a}$ of Article XXIV [Domiter 2008, p. 124].

\subsection{The evolution and codification of the Most Favoured Nation clause (MFN) in the interwar period}

The post-war division of the world into two camps was also reflected in the use of the most-favoured-nation clause. There are two trends to be distinguished. The first is the tendency to limit the scope of the clause or to exclude a certain group of countries from it. One such a project was a ban on the use of the MFN by the Central Powers: Germany, Austria-Hungary, Turkey and their allies. Among other initiatives meant to reduce the operation of the MFN there was e.g. the integration of the Central European Countries, which on the one hand was based on the clause, but on the other it could not be applied to countries outside of the system. World War I also led to the renunciation of the agreement between France and Germany, which provided eternal building of mutual relationship between the two countries on the basis of the MFN. Generally, there was a tendency to limit the trust towards other countries and the importance of the MFN was regressing when compared to how important it had been before the war. The second trend was the reconstruction of international relations between the winning states on the basis of the clause. The use of the MFN was imposed for example on Germany under the Versailles Treaty. It contained provisions saying that Germany was obliged to treat goods imported from the allied countries with all the privileges and advantages that goods imported from other states would receive. Similar unilateral clauses were applied to other losing countries [Kałduński 2006, pp. 51-59; Dobrzycki 2010, pp. 183-185].

One of the consequences of World War I was that countries retreated from liberalism and diverted to protectionism. A strong tendency appeared to curb international exchange, the trend that individual countries should rebuild their economies with their own resources, as well as the mistrust of others caused the MNF to lose its importance in trade relations in this period. Although it was initially often related to in the course of the reconstruction of the post-war world, it never managed to regain the popularity it had had before the war. This did not change even when the United States abandoned the practice of using the conditional clause and became 
increasingly willing to sign international agreements containing an unconditional MFN. The Great Depression of 1929 affected the MFN very badly. The stock market crash which began on Wall Street led to recession in many countries around the world and caused a return to protectionism, even though the tendencies to open the economies and to use the MFN had begun to revive prior to the stock market crash [Szpak 2007, pp. 288, 298-301].

\section{The development of the MFN after the Second World War}

World War II brought about a considerable number of changes. One of the most important ones was the end of European primacy, as the continent had to hand its leadership in international relations over to the United States, and the division of the world into two competing blocks, the symbol of which - since Winston Churchill's speech in Fulton - became the "iron curtain" [Micun 2002, p. 341]. The tragedy of the Second World War was an impetus for the world to do its best in order to prevent such disasters in the future. The sign of this in Europe was the integration of the Western countries in order to build an economic community [Borowiec, Wilk 2005, p. 40]. On the global scale, this led to the creation of the United Nations and to the endeavours to build a world order.

The integration trends also emerged in the field of economics. The first two international organizations of an economic character were established as early as in the years of World War II. These were the World Bank and the International Monetary Fund, both created in 1944 [http://web.worldbank.org/...dated 12.05.2011; http://www.imf.org/... dated 12.05.2011]. Three years later the General Agreement on Tariffs and Trade (GATT) was formed. The first article of its statute contains an explicit reference to the most-favoured-nation clause [Hoekman, Kostecki 2011, pp. 210-211; http://www.wto.org/]. Thanks to this provision, the MFN became the basis for a new, liberal economic order in the world. The importance of the clause itself for international trade became greater with the increase in the number of countries united, first in the GATT and then in the WTO. The fact that the MFN was the basic principle on which this system was to be built should be considered a restitution of its importance in international trade. The multilateral nature of the clause adopted by the GATT also marked the beginning of replacement of bilateral MFNs with multilateral agreements based on this institution. Article I of the GATT has so far been the most vital clause of the MFN ever to appear in international law, and this is caused by the already mentioned abundant membership of WTO, which implies the universality of the principles and norms the organisation has established.

Since the sixties, the MFN has also been an object of interest to the International Law Commission established by the United Nations. The first attempts to codify it took place in 1964, but they were unsuccessful. Five years later the matter was referred to again. In 1969 a long and complicated process of codification began. It lasted until 1991. During this process, two successive rapporteurs gathered the documentation related to the MFN. The case-law of the International Court of 
Justice was collected as well. Despite such efforts to systematize the most-favoured-nation clause (which is an institution of international law), there was no success. Ultimately, the codification project was abandoned and MNF concluded that the codification was not necessary. However, the fact remains that within the committee itself there was - and perhaps still is - a conviction that the MFN is crucial as an element of the law of treaties [Kałduński 2006, pp. 94-102].

As the MNF's actions and the provision in Article I of the GATT show, the MFN has been a very popular institution of international law since the end of World War II. It is significant in this context that it does not have its own place in the Common Trade Policy of the European Union or in the regulations of domestic law. Under EU trade policy, the MFN is applicable to countries which are not given preferential treatment. The use of the clause in the tax law within the EU seems more interesting [Wiktor 2005, p. 179; Zalesiński 2004]. Despite the absence of explicit provisions in the community law, the universality of the MFN and the role it has gained over the years has an impact on relations among the European Union countries.

\subsection{Factors limiting the scope of application of the MFN}

Liberalising tendencies, especially the functioning of the GATT/WTO, promoted the development of the role of the MFN. However, there were also some circumstances which limited its significance.

The first factor is the Generalised Scheme of Preferences (GSP). It was adopted by the United Nations Conference on Trade and Development during a meeting in New Delhi in 1968. Its purpose was to intensify trade, achieve industrialization and foster rapid economic growth in the group of underdeveloped countries. This system was characterized by non-discrimination, universality and the lack of reciprocity [Wymiana handlowa... 2004, p. 24]. After its adoption, the GSP became the leading factor regulating trade relations with countries with the low level of economic development. It replaced the MFN clauses. This can be seen very clearly in the situation of the European Union, which replaced the MFN standard with GSP and GSP+ (additional preferences for countries with insufficiently diversified trade and relatively low exports to the EU internal market) [http://www.mg.gov. pl/... dated 19.05.2011; Wymiana handlowa... 2004, pp. 27-28] in its relations with underdeveloped countries. Given the fact that other countries have acted similarly in their relations with developing countries and LDCs, the conclusion that must be drawn is that this has led to a restriction of the use of the MFN in trade relations on the global scale.

The second factor is the tendency to displace the MFN with some even furtherreaching liberalization agreements. The politics of the GATT/WTO focuses more on the reduction of duties than on their total abolition, whereas the EU goes further in its trade policy - it aims at the complete abolition of customs duties and measures which have similar effects [Nyka 2010, pp. 72-73]. Moreover, the Free Trade Area 
has become an increasingly popular form in international economic relations, which can be proved by the fact that the EU has been negotiating the creation of the Free Trade Area among others with ASEAN (Association of South-East Asian Nations), MERCOSUR (South American economic organization which unites Argentina, Brazil, Paraguay, Uruguay and Venezuela), India, China, Japan and Russia [http:// www.mg.gov.pl/... dated 19.05.2011].

\subsection{The place of the MFN in the GATT/WTO}

The idea to create an international organisation responsible for trade matters was connected to the MFN from the very beginning. The initial assumptions provided that the MFN was to become one of the cornerstones of ITO when it was being founded. The United States advocated this role of the clause ardently. During the talks whose aim was to conclude the General Agreement, much time was devoted to the formulation of the wording in which the MFN is now found in the text of the GATT $^{3}$. After considering a number of issues, the following form of Article 1 was accepted: "Any advantage, favour, privilege or immunity granted by one contracting party to any product originating in any other country or destined for that country shall be immediately and unconditionally extended to the like product originating in or destined for the territories of the contracting parties. This provision applies to customs duties and charges of any kind imposed in connection with importation or exportation, or charged for transmitting abroad the import-export payments, the procedure of collecting charges and fees, all rules and formalities concerning imports or exports, and all matters referred to in paragraphs 2 and 4 of Art. III" [Kałduński 2006, pp. 305-306].

The main task of the GATT/WTO has been the promotion of free trade, liberalization by lowering customs duties and bans on the use of non-tariff barriers, intensification of trade in the global economy and the promotion of peaceful

\footnotetext{
3 The General Agreement (like an international agreement) consisted of a preamble and 38 articles in four parts. Its official text (known as GATT 1947) had been in force until the creation of the World Trade Organization. The first part of the Agreement, which contains Articles I and II, forms the basis of the General Agreement. It contains the MFN clause. The second part (Articles III-XXIII) concentrated on the topic and provisions related to non-tariff measures, restricting of unfair competition (among others anti-dumping and anti-subsidy duties). It also contained provisions on exceptions to the general rules of the Agreement and national treatment clause. An interesting entry in this section was the so-called grandfather clause, which assured the signatories that their national trade regulations would not be changed when GATT entered into force if they were different from the regulations contained in Part Two. The third section included Articles XXIV-XXXV. Subject to regulation in this part were the changes in granted concessions, procedural matters and exceptions to the rules of the GATT, including the previously mentioned exceptions to the MFN related to the creation of preferential trade agreements (free trade areas and customs unions). The fourth section was added to the Agreement in 1965 as a result of pressure from underdeveloped countries. It contained Articles XXXVI-XXXVIII, which were directed to developing countries. The articles referred to the special privileges in the field of trade granted to this group of countries. See: [Domiter 2008, p. 332].
} 
coexistence of the countries by reducing economic conflicts, together with the possibility of peaceful resolutions of trade disputes. After the GATT was created and based on the MFN, the possibilities of manipulating the duty rates and making them dependent on the prevailing trend were significantly restricted. The formula of the compulsory clause which is included in Art. I of the GATT provides that the progress of liberalization in the global economy will be conducted much faster than if it took place on the basis of bilateral or even multilateral agreements, but on a smaller scale than the General Agreement. The positive effects of MFN multiplied along with the increase in the number of members. It should also be noted that only some of the exemptions from the application of the MFN which exist in the GATT/WTO are conducive to protectionism, while a substantial number of them repeal the clause in favour of a more advanced trade liberalization [Kałduński 2006, pp. 51-52].

The main area in which the MFN clause is applicable is the trade in goods ${ }^{4}$.

\section{The importance of the MFN clause for underdeveloped countries}

Due to the diversity of countries defined as "underdeveloped", they can be divided into four categories: Least-Developed Countries (LDCs), oil countries I, oil countries II and other economically underdeveloped countries ${ }^{5}$.

The GATT/WTO was intended to be a global system, the basis for dialogue with the widest possible range. Therefore, countries defined as underdeveloped were already a part of the contracting parties forming the General Agreement. Their role,

\footnotetext{
${ }^{4}$ However, its importance for GATS and TRIPS (Agreement on Trade-Related Aspects of Intellectual Property Rights) cannot be overlooked.

${ }^{5}$ Least Developed Countries include countries with the lowest per capita GDP (less than 900 USD), the lowest rates related to life standard measured by the level of adult illiteracy, education and health care, as well as developing countries (the underdeveloped ones) i.e. countries with low and average income per inhabitant, which, according to the World Bank, can be determined at the level of 3,945 USD, and the developed countries whose per capita income exceeds 3,945 USD. This is a rather conventional division; many point to the fact that in addition to GDP per capita one should also take into account the structure of the economy (the share of agriculture in total GDP), or the structure of exports (exports of low-processed goods, agricultural goods and raw materials and commodity characterizes countries with the low level of economic development). Oil countries I: Saudi Arabia, the United Arab Emirates, Kuwait, Libya and Qatar. A characteristic feature of these countries is the fact that they achieve a positive trade balance thanks to the export of crude oil and spend these funds on domestic investment (infrastructure, modern technology, manufacturing, agriculture), import of technology and attracting different types of specialists needed in terms of the economy. They also have a tendency to spend much money on imports of consumer goods, especially luxury products. Countries Oil II are the other Member States of OPEC (Organization of Petroleum Exporting Countries) and some oil-exporting countries which are not affiliated to the organization. The main difference is that they usually record negative trade balance, and their export earnings are not sufficient for the needs of their economies. See: [Bożyk 2004, pp. 212-217].
} 
however, was marginal for a long time and the main decision-maker was the triad: the U.S., Western Europe and Japan. Nevertheless, the GATT/WTO created a set of rules which application can bring real benefits to developing countries. They relate to the ban on discrimination, the right to the protection of the internal market, the principle of reciprocity, national treatment and the MFN [Kraje rozwijajace się... 2007, pp. 317-322.]. Particularly important from the point of view of the underdeveloped countries is the fact that the contracting parties of the GATT were aware that some requirements of the General Agreement could adversely affect the economically weaker partners. Thus, in order to ensure that the coverage of the Agreement was as wide as possible, it was agreed that some concessions to the underdeveloped countries be made. Such concessions were first made in the 1950s, when developed countries asserted that only special treatment would give underdeveloped countries a chance to develop; they agreed on this under the influence of Raul Prebisch's and Hans Sinder's theory. In this way the idea of SDT (Special and Differential Treatment) was created. Part IV of the GATT and the GSP is of particular importance for the SDT. The concessions made to developing countries are discretionary, i.e. they depend on the will of a state which grants such special treatment. In addition to Part IV of the General Agreement, the so-called Enabling Clause plays an important role in the preferential treatment of economically weaker countries [Czubik 2002, pp. 37-38].

Part IV of the GATT became the gateway for underdeveloped countries to achieve their privileged position under the GATT/WTO. The main indication that the MFN should be replaced with SDT in relations with economically underdeveloped countries was the assumption that trade liberalization on pain of the most preferential treatment does not necessarily help the growth and economic development of underdeveloped countries [Hoekman 2005, p. 224]. It is particularly noticeable in the use of Article XXIV, in the reference to the fourth part of the Agreement. This makes the creation of free trade areas between the highly developed countries and developing countries possible. Such agreements are based on discrimination against economically developed countries. Trade privileges, including customs privileges, are granted unilaterally to economically weaker countries, whereas highly developed countries do not receive any additional benefits. An example of such an agreement may be the Lomé Conventions, on which the European Union trade relations with the countries of the ACP (Africa, Caribbean and Pacific) are based. They were given free access to manufactured goods and numerous concessions in exports of agricultural commodities to the Community. The possibility to create such agreements in a sense afflicts the overriding purpose of the WTO which is the promotion of free trade. The aim of the exemptions from the application of the MFN under Art. XXIV was, by definition, to allow for the creation of structures for more advanced trade liberalization. When liberalization is one-sided, however, it causes some business relationships to base on discrimination. One can, therefore, assume that Part IV of the GATT validated the category of free riders, as developing countries are free to 
exploit the negotiated trade privileges, not offering anything in return [Wymiana handlowa... 2004]. It is, of course, rather a formal objection, for the most important thing from the perspective of the real liberalization of the global economy is the reduction of barriers in the trade among the largest and most powerful entities.

The second instrument in the GATT/WTO system operating for the benefit of developing countries is the Enabling Clause. It was established during the Tokyo Round and its official name is "Differential and more favourable treatment reciprocity and fuller participation of developing countries". The Enabling Clause gave the System of Preferences a legal basis. It also provided developing countries with a number of privileges, e.g. it repealed the MFN. The Enabling Clause became a way to circumvent the rules of the GATT/WTO system in the trade relations between developing and underdeveloped countries. What made the circumventing even easier was the fact that the rules of using the Enabling Clause were not very clear, the formal requirements were not precise and so on. As a result of this, all regional agreements relating to the clause were accepted, regardless of whether they were in compliance with the exact wording of the clause or not [Hoekman, Kostecki 2011, p. 565].

Already during the Uruguay Round a considerable involvement of developing countries was to be seen. But it was the Doha Round in 2001 that really focused on the problems of economically underdeveloped countries. The biggest chance for these countries would be if the highly developed countries opened their markets for agricultural products from developing countries. According to the estimates of the United Nations Development Programme (UNDP) from 2005, the total abolition of export subsidies and a significant reduction of subsidies for food production in the richest countries would result in the global GDP increasing by $\$ 50$ billion dollars, $60 \%$ of which would go to underdeveloped countries. In the course of this round of negotiations, developing countries, under the aegis of Brazil, created a front opting for cessation of agricultural subsidies in the EU and in the U.S. and for the abolition of protectionism towards these entities in the field of agriculture. However, the compromise was not reached and in 2006 the Doha Round was suspended indefinitely [Ekonomia rozwoju... 2010, pp. 15-22].

\subsection{Most Favored Nation Clause in the economic policy of economically underdeveloped countries}

The developing countries that are members of the WTO, in theory are subject to the same rigors and rules which other Member States of the organization are subject to. However, the actual extent of the rights and obligations of this group of countries, related to their membership, is different than it is for highly developed countries. The most interesting aspect is the extent of use of the Most Favored Nation clause in the group of countries with a low level of economic development. Certainly, the most important variable in the GATT/WTO system, the functioning of MFN in developing 
countries, was waiver of 25 June 1971. Thanks to the derogation from the rules of the General Agreement, it was possible to use the Generalized System of Preferences towards the developing countries. This was crucial, since GSP, in fact, replaced the MFN clause, as the supreme rule in trade relations of the underdeveloped countries with the developing countries. It is worth noting that, in contact to MFN, which prohibited discrimination, in the generalized system of preferences the differential treatment of the developing countries by the developed countries was possible. Awarded by highly developed countries, reliefs and customs privileges depended on the arbitrary decisions, which greatly disrupted order built on the basis of MFN regime. Although, the waiver was valid for only 10 years, which would have resulted in the restoration of the MFN clause in the trade relations by developing countries highly developed countries, larger passed legislation-Enabling Clause, which caused its regulation, became an integral part of the GATT/WTO system [Michałek 2002, p. 119]. Facilitations clause is inextricably linked to the legitimacy of the Generalized System of Preferences under the GATT/WTO, and consequently the reduction of MFN importance for developing countries. The adoption of Enabling Clause for two years before the expiry of the waiver, which was mentioned previously, gave a legal basis for the indefinite use of the GSP. In this way, there is a constant substitution of the MFN clause in this system. On the one hand, it was able to obtain more favorable conditions than those resulting from the MFN; on the other, there is a lack of fully clear rules and possibilities of selective granting of preferences, that could cause and result in a number of trade disputes. However, the fact is that developing countries benefit from the preferences granted to them by the means of facilitations clause, including relations with the European Union. As a result, still small, but steadily growing (in 2000-2007 the increase in import from the EU by 15,1\%, and export to the EU by 27,7\%), the flow of trade between the ACP countries and the EU is based on the GSP or more far-reaching concessions from the EU. Facilitations clause is also relevant to the other mechanism used by the developing countries, also repealing the use of MFN. It is about the creation of zones of preferential trade between the underdeveloped countries. These zones are a middle way between free trade and trade on the basis of the most privileged ones. Customs duties lay down different (larger) than zero, but less than those of the MFN clause. With more flexible rules and less demand, creating zones of preferential trade is easier than creating zones on the basis of free trade according to Art. XXIV of GATT. To facilitate this, important for developing countries causes the increase of regional agreement shares governed by the rules other than MFN [Czubik 2002, pp. 37-38].

Such a spectrum of possibilities for underdeveloped countries makes the scope of their use of the MFN is small. On the one hand, the trade with developed countries based on the GSP is very important for these countries, but on the other, they can create preferential agreement or free trade on their territory. Thus, the MFN clause will be applicable for them in the trade with other developing countries, which are members of the WTO and are not in their geographic proximity. The obligation to 
comply with the MFN principles of mutual relations in developing countries requires the interpretation of Art. XXXVI par. 8 of GATT [Czubik 2000, p. 91]. However, the theory that the whole trade of highly developed countries with developing countries is based on the GSP, contradicted the evidence prior to 2001, as almost 50\% of the EU's trade with least developed countries outside the AKP was based on the MFN, and not on the GSP system [Stiglitz, Charlton 2007, p. 71]. A slightly different light is shed on the use of MFN in underdeveloped countries in the Least Developed Countries Report 2010 published by UNCTAD. In this report, there is the MFN clause in the context of tariff barriers for agricultural products. This area, particularly sensitive for almost all highly developed countries, is mostly covered by separate legislation. It is no different in the case of trading rules in the WTO. The United States still maintain more than $8 \%$ of the customs duty on agricultural goods from the LDCs, based on the MFN clause. What is more, preferential custom duties for the least developed countries used by the US in the area of products of agricultural origin are on average $6 \%$ higher than those by the developing countries, This may prove that owing to the trade relations of underdeveloped countries with the developing countries, MFN has a totally different role than assumed in the establishing the pillars of the GATT/WTO system. In the area of agricultural goods, it will not contribute to the liberalization of trade between the two groups of countries, or even, as in the example above, it is not a source of the creation of barriers to trade [Least Developed... 2010, p. 62].

There is a clear difference in the level of customs duties in highly developed economies and other remaining groups. In all groups of countries, the average customs duties under the MFN are highest for agricultural products. This area is similar to the customs protection in LDCs and other developing countries (hovering around $16 \%$ ), by more than 6 percentage points lower than customs duties on goods of agricultural origin in countries under economic transition, and in highly developed countries the difference is just ten percentage points (average customs duty is just under 6\%). In the case of industrial goods and the trade, differences between the least developed countries and developing countries are already larger. Duties arising from the MFN for industrial goods in LDCs are on average over 12\% and are about three percentage points higher than in other underdeveloped countries, where the total trade ratio is about $12,5 \%$ to about $10 \%$, so the difference is two and a half percentage points. In both categories, countries undergoing economic transition are closer to the developed countries. Both, in trade of commercial and industrial goods and in the overall customs protection, the differences are within 1\% (in "transforming" countries about $5,8 \%$ and in highly developed countries about $6 \%$, both at around $5 \%)$. As the authors of the report draw attention, despite significant differences in the rates of customs duty in the last two categories, they are too low (single digit) to provide strong additional protection of domestic industry in the group of LDCs (especially in the group of developing countries) [Least Developed... 2010, p. 92].

One of the conclusions that has attracted the attention of the authors of the report is the fact that some highly developed countries and quite a large number of countries 
with economies in the phase of transformation have a higher customs security which stems from the MFN than some of the countries which are least developed. Only within the group of least developed counties (including LDC and other developing countries) do we notice medium customs rates which stem from the MFN clause which exceeds $18 \%$, while the highest ones appear in the countries from the group of developing countries (at or exceeding the level of $30 \%$ ), and not among the least developed ones.

The authors of the report point to the fact that the difference between the level of the fixed customs rates which stems from MFN is so large, that it allows for a significant maneuver of possibilities for the countries which are least developed. As it is seen in practice though, they do not tend to be flexible enough and do not avail of this in order to conduct an active politics in favor of the development of their trade [Least Developed... 2010, p. 183].

Differences between both values are rather mostly significant, and sometimes exceed one hundred percentage points. The largest variance is noted in case of Bangladesh, which has the customs rate of $170 \%$, while the one which stems from MFN is barely $20 \%$. Apart from this country the second largest variance is visible for Tanzania with customs rates of $120 \%$ respectively and approx. $16 \%$. At the other extreme are Cambodia and Mauretania. Both these countries experience variance between the levels of the two rates and do not exceed five percentage points. Only two countries (Djibouti and Maldives) have the customs rate based on MFN which exceeds 20\%; Chad, Ruanda, Gambia and the Republic of Middle Africa have the rate equal or very close to $20 \%$. Haiti has a visibly lower rate stemming from MFN (approx. 1\%) and this country together with Cambodia and Mauretania also has the lowest level of fixed customs rates (20\%) [Stiglitz, Charlton 2007, p. 174].

While comparing average rates it is quite visible that in all cases the tariff stemming from MFN is higher than the one of GSP. The highest variance exists in case of the United States, where there is a zero customs rate for GSP, while MFN equates to 5.59. The smallest difference is $1.6 \%$ for the rates of Canada, but Canada also uses the lowest tariff resulting from the MFN. The greatest degree of protection of the internal market is applied by the European Union, which both for MFN and GSP has the highest value (7.07 and 5.23 respectively). The situation is different in the analysis of weighted average rates. In this case, lower values are applied to rates resulting from MFN; only in the case of USA lower (because of zero) is the rate of the GSP. The smallest difference, but at the same time the highest values, are shown by weighted average EU rate (3.56\% for MFN and $4.54 \%$ for GSP); Canada has the lowest rate of MFN (1.27\%), but a high one for GSP (4.18\%) [Least Developed... 2010, p. 184].

The above data indicate that the liberalisation of trade based on MFN (Most Favoured Nation Clause) develops differently in various countries. Developing countries take advantage of a much higher duty protection than transforming and highly developed countries. The scale of liberalisation of tariff rates has also been 
huge in the weakest developed countries under the pressure of MFN. The average tariff rate resulting from MFN in the European Union in 1999 had the value corresponding better to this indicated by "other developing countries" than by the economically developed countries (which only in two cases had the tariff rates higher than 6\%). Also the countries using GSP (Generalised System of Preferences) obtained benefits for this reason. However, except for the trade with the USA, in other cases the benefits were relatively small.

Summing up: Most Favoured Nation Clause is not an institution of international law with particular significance for the weakly developed countries. MFN not only does not play a leading role in trade with developed countries, but it also plays a negative role for them. This negative role is reflected in various aspects. On the one hand it is still a high level of tariff rates in the area of agricultural goods, which are often the main source of export of the developing countries. Abandoning the liberalisation of tariff rates based on MFN by weakly developed countries, makes them lose a possibility of sufficient protection of their internal markets. As a paradox, the liberalisation of the world trade based on the Most Favoured Nation Clause also affects negatively the developing countries as along with the decline of a general level of tariffs, the difference and benefits which the countries have of the GSP also diminishes. In the light of the presented analysis the course of thinking applied in creating regulations alternative to MFN for the weakly developed countries being the members of GATT/WTO seems correct. Naturally a question whether the application of previous and present means is efficient and whether new solutions are to be sought is still disputable.

\section{Influence of foreign trade on the growth in developing countries - summing up}

A degree of influence of foreign trade on economic growth, and thus on development in a developing country depends on a selection of a model of economic transformation: liberalisation or protection. For international trade is often perceived as an instrument of exploitation of peripheries by a centre, the countries belonging to the centre became supporters of free trade, whereas the peripheries are trying to limit the process of exploitation of their economies by a variety of forms of protectionism. Thanks to market protection and simultaneous subsidising of production, peripheral manufacturers have time to enhance their production and internal markets which prepares them for further competition in international market and taking advantage of trade as a factor of economic growth. The choice between free trade and protectionism has, however, a political background. Due to the huge efficiency of own production after 1945 the United States have become a promoter of free trade. However, they allowed Western Europe, Japan, Taiwan and South Korea, in order to consolidate the alliances against the Soviet Union, to complete their protectionism programmes. This permission lasted till the end of the 1970s, until the development 
of these countries and their commercial expansion started to threaten the position of the United States. This kind of politics is illustrated by the negotiations lasting in the forum of GATT/WTO as the subject of liberalisation became the areas of trade in which the USA and other highly developed countries had a significant competitive advantage. At the same time trade with agricultural goods so important for the peripheral countries was omitted.

Summing up one may state that trade is not only an endogenic factor of growth and development of developing countries, but also affects the relocation of countries (regions) between the central and peripheral areas. However, the efficiency of this factor depends on global rules for exchange, including also the influence of MFN.

\section{Conclusions}

The Most Favored Nation Clause (MFN) has been present in the international relations since the late middle ages in the relations among European countries. Since that time it has been widely applied in bilateral agreements concerning non-preferential trade. It was also applied in the framework of the trade settlement aspiring to regulate wide, or even global, trade relations. The MFN clause is not an institution in the international law of particular significance for the least developed countries. MFN not only does not play a leading part in the trade with the developing countries, but it often fulfils a negative role for such countries. On the one hand it still remains on the relatively high level of customs rates in the region of agricultural goods which are often the main product of export for the developing countries. On the other the liberalization of customs rates based on MFN for the countries from the group of the least developed ones results in losing by them the possibility of sufficient protection of their internal markets. Paradoxically the world trade liberalization based on the MFN clause also negatively influences developing countries, due to the fact that together with the decrease of the general level of duty the difference and the benefit which such countries have from the GSP system also decreases. On the basis of the presented analysis, the concept of thinking which was taken when creating an alternative towards MFN regulations for the least developed countries being the GATT/WTO members, seems right. Of course, the disputable matter whether the previously applied and current resources are effective and whether new solutions should not be sought remains a question.

\section{References}

Borowiec J., Wilk K., 2005, Integracja europejska, Wydawnictwo AE Wrocław, Wrocław. Bożyk P., 2004, Zagraniczna i międzynarodowa polityka ekonomiczna, PWE, Warszawa.

Czubik P., 2000, Odstepstwa od zasad i regut systemu GATT/WTO w stosunkach z państwami rozwijajacymi się, [in:] Problemy handlu międzynarodowego, eds. K. Budzowski, S. Wydymus, Wydawnictwo AE Kraków, Kraków. 
Czubik P., 2002, Wolny handel towarami. Podstawy międzynarodowego regionalizmu handlowego, Kantor Wydawniczy Zakamycze, Kraków.

Dobrzycki W., 2010, Historia stosunków międzynarodowych 1815-1945, Scholar, Warszawa.

Domiter M., 2008, Eksport w doktrynie i polityce gospodarczej na tle procesów liberalizacyjnych $i$ integracyjnych, Wydawnictwo AE Wrocław, Wrocław.

Ekonomia rozwoju, 2010, eds. B. Fiedor, K. Kociszewski, Wydawnictwo UE Wrocław, Wrocław.

Ekonomia rozwoju, 2007, ed. R. Piasecki, PWE, Warszawa.

Epping R.Ch., 2002, Przewodnik po światowej ekonomii, Wydawnictwo Studio Emka, Warszawa.

Gilas J., 1976, Klauzula największego uprzywilejowania, [in:] Encyklopedia prawa międzynarodowego i stosunków międzynarodowych, Wiedza Powszechna, Warszawa.

Hoekman B., 2005, Beyond Special and Differential Treatment, [in:] Reforming The World Trading System. Legitimacy, Efficiency, and Democratic Governance, ed. E.U. Petersmann, Oxford University Press, New York.

Hoekeman B., Kostecki M.M., 2011, Ekonomia światowego systemu handlowego. WTO: Zasady i mechanizmy funkcjonowania, Wydawnictwo UE Wrocław, Wrocław.

http://www.imf.org/.

http://www.mg.gov.pl/

http://web.worldbank.org.

http://www.wto.org.

Hudec R.E., 1987, Developing Countries in the GATT/WTO Legal System, Rowman \& Littlefield, Washington.

Jackson J.H., 1997, The World Trading System - Law and Policy of International Economic Relations, MIT Press, Cambridge.

Kraje rozwijajace się w światowym systemie gospodarczym, 2007, ed. P. Miklaszewski, Difin, Warszawa.

Kałduński M.M., 2006, Klauzula największego uprzywilejowania, Dom Organizatora, Toruń.

Least Developed Countries Report 2010: Towards a News International Development Architecture for LDCs, 2010, UNCTAD, New York, Geneva.

Latoszek E., Proczek M., 2001, Organizacje międzynarodowe. Założenia, cele, działalność, Wydawnictwo WSHiFM, Warszawa.

Michałek J., 2002, Polityka handlowa. Mechanizmy ekonomiczne i regulacje międzynarodowe, Wydawnictwo Naukowe PWN, Warszawa.

Micuń J., 2002, Historia, od starożytności do współczesności. Vademecum, Translator, Warszawa.

Nyka M., 2010, Handel światowy w zintegrowanym porzadku prawnym, Ars boni et aequi, Poznań.

Procesy integracyjne dezintegracyjne w gospodarce światowej, 2007, ed. K. Żukrowska, SGH, Warszawa.

Samuelson P.A., Nordhaus W.D., 2004, Ekonomia 2, Wydawnictwo Naukowe PWN, Warszawa.

Stiglitz J.E., Charlton A., 2007, Fair Trade, Szansa dla wszystkich, Wydawnictwo Naukowe PWN, Warszawa.

Szpak J., 2007, Historia gospodarcza powszechna, PWE, Warszawa.

Wiktor J.W., 2005, Rynek Unii Europejskiej, koncepcja i zasady funkcjonowania, Wydawnictwo AE Kraków, Kraków.

Wymiana handlowa UE z wybranymi regionami świata, eds. J. Rymarczyk, M. Wróblewski, Oficyna Wydawnicza Arboretum, Wrocław 2004.

Zalesiński A., Umowy o unikaniu podwójnego opodatkowania a problem standardu najwyższego uprzywilejowania w europejskim prawie wspólnotowym, KPP Nr 3/2004. 


\section{ZNACZENIE GLOBALNYCH REGUL PROWADZENIA WYMIANY HANDLOWEJ ZE SZCZEGÓLNYM UWZGLĘDNIENIEM KNU DLA KRAJÓW ROZWIJAJĄCYCH SIE}

Streszczenie: Artykuł jest próbą wskazania na rolę polityki handlowej w umożliwieniu poszczególnym krajom wydźwignięcia się w handlu światowym do sfery wyższych wartości dodanych. Stosując taką politykę Azja Wschodnia odniosła sukces, a Ameryka Łacińska nie. We wszystkich krajach rozwijających się można zauważyć korzyści płynące z liberalizacji importu, która była częścią strategii ograniczania ubóstwa i przyspieszania wzrostu, jednak o tym czy strategia liberalizacji przyniosła pożądane efekty decydowała konstrukcja reform, tempo ich wprowadzania oraz kolejność. Prawdziwy sukces gospodarczy osiągnęły jednak te kraje rozwijające się, które stosowały politykę rozwoju przez eksport.

W artykule postawiono trzy tezy:

- handel zagraniczny jest potężniejszym czynnikiem wspierającym rozwój krajów najuboższych niż kierowana do nich pomoc zagraniczna, a jego rola wzrasta wraz z ogólnym rozwojem kraju ${ }^{6}$,

- handel zagraniczny determinują globalne reguły jego prowadzenia, stąd kraje rozwijające się muszą włączyć się w system międzynarodowej koordynacji polityki handlowej,

- KNU choć znajduje zastosowanie w ramach układu handlowego aspirującego do regulowania szerokich, wręcz globalnych, relacji handlowych, to liberalizacja handlu światowego na jej podstawie również negatywnie wpływa na państwa rozwijające się, ponieważ wraz ze spadkiem ogólnego poziomu ceł zmniejsza się różnica i korzyść, jaką państwa te mają z systemu GSP.

Słowa kluczowe: polityka handlowa, reguły polityki handlowej, kraje rozwijające się, KNU.

\footnotetext{
${ }^{6}$ Pomoc rozwojowa jest skuteczna tylko w tych państwach, które mają zdrowe środowisko makroekonomiczne, dysponują efektywną administracją i sektorem publicznym oraz prowadzą otwartą polityką handlową.
} 